\title{
Assessing the Seamlessness of Bangkok Metropolitan Public Transport by using Modified Quantitative Gap Analysis
}

\author{
Ariva Sugandi Permana \\ Department of Civil Engineering, Faculty of Engineering, King Mongkut's Institute of Technology Ladkrabang, Bangkok, Thailand \\ Email: ariva.pe@kmitl.ac.th
}

\section{Arthit Petchsasithon}

Department of Civil Engineering, Faculty of Engineering, King Mongkut's Institute of Technology Ladkrabang, Bangkok, Thailand

\begin{abstract}
A sustainable transportation system requires a larger contribution to public transport share in comparison to private transport. Bangkok Metropolitan, the study area, exhibits a significant transport modal alteration trend towards public transport, in line with the expansion of Bangkok Transit System (BTS) and Mass Rapid Transit (MRT) for more coverage within the metropolis along main roads along with expansion of public bus routes, which increases the seamlessness and reduces transit time. This study is important as we believe that the higher seamlessness the more urban travelers would shift to using public transport modes. This matter is considered as a pertinent urban transport problem. This study aims at understanding the level of transit seamlessness of the Bangkok public transport system. The study was carried out by firstly measuring six factors of the regular transit process, on formal and informal transport modes used by Bangkokians. These six factors were observed along the origin and the destination of the travelers with respect to travel time, number of transit points, average transit time, comfort, and transit facilities including facilities for disables, and walking distance. A total number of 300 public transport users were selected as respondents, 50 respondents for each selected transit hub. The selection was based on convenient random sampling considering the variability of destinations and purpose of travel. Despite a different destination, the residence was set as the origin. By using Modified Quantitative Gap Analysis, based on six selected transit hubs, the study found that the seamlessness of the inter-modal transits in Bangkok exhibits a characteristics of hard transit process, particularly for disabled people, notwithstanding the continuous efforts to make the seamless transit are in place, particularly with respect to infrastructure facilities.
\end{abstract}

\section{Article History}

Received : 20 July 2019

Received in revised form : 06 August 2019

Accepted: 10 September 2019

Published Online: 31 December 2019

\section{Keywords:}

Public transport, transit system, seamless transit, formal transport, informal transport modes.

\section{Corresponding Author's Contact:}

ariva.pe@kmitl.ac.th

DOI: $10.11113 /$ ijbes.v7.n1.440 


\section{Introduction}

Sustainable transportation system becomes a common ultimate goal of many cities in managing their urban transport to serve the citizens (Schiller \& Kenworthy, 2017), as it is claimed to possess the elements of sustainability based on sustainability indicators (Haghshenas \& Vaziri, 2012). Haghshenas \& Vaziri (2012) also asserted that the problem of urban mobility and environmental impacts are today's major issues in the metropolis in the world. This is a critical barrier in accomplishing sustainable urban development. Since one of the objectives of sustainable transportation is coping with the air pollution stems from the transport sector (McCormick, et al., 2013), sustainable urban development and sustainable transport are, therefore, shared common issues towards sustainable development.

Seamless transit process is one of the essential components of a sustainable urban transportation system (Loo \& du Verle, 2017; Haque, Chin \& Debnath, 2013). A seamless transit is an easy and smooth intermodal transfer experienced by urban travelers, which has a potential power to attract more public transport users and pedestrians, and thus promoting sustainable urban transportation from the way it reduces per capita emission stems from urban transportation and promotes welfare in the society. The increased share of public transport over private transport may lead to strategic multiplier effects towards sustainable transportation system (Litman, 2015). A transportation system is said to be sustainable when the environmental impacts i.e. noise, air pollution due to emission, and waste generated by the system are within the acceptable limit. The system should have no or trivial impacts on climate change. Moreover, the transportation system should bring economic growth to the city and societies and promote citizens welfare through widening access and equity for the whole citizens (Carmon \& Fainstein, Eds., 2013). With this broad vision of sustainable transportation, Kamargianni et al., (2016) argue that the seamless transit does not directly contribute to a sustainable transportation system, rather indirectly but strongly support the elements of sustainable development, in a way that greater contribution of public transport would reduce emission and transport energy and therefore reducing greenhouse gas emission, reducing environmental impacts and climate change.

The transit system in Bangkok Metropolitan involves formal and informal transport modes. Formal transport mode in this regards is any mode of transport, which are formally recognized by the authority and legally formalized. Informal transport mode, on the other hand, is may be recognized by the authority but does not legally formalize by law. Günther \& Launov (2012) and Pugh (2013) asserted that cities in developing countries are a predominant harbor of the informal sector for one strong reason which is the characteristics of the informal sector is perfectly compatible with the conditions of developing countries. In Bangkok Metropolitan, there are basically nine or ten formal and informal transport modes. The seamlessness of the intermodal transit in Bangkok Metropolitan seems an essential issue to be solved to attract more public transport users. This study attempts to understand this issue. A casual survey by the authors shows that transit process in most available hubs in Bangkok is a thoughtful issue to be pondered by public transport authorities in Bangkok.
Table 1 exhibits samples of intermodal transit variables acquired in a pre-research survey by authors.

Table 1 Seamlessness Intermodal Transit Variables at selected hubs measured during pre-research survey

\begin{tabular}{l|r|r|r}
\hline Aspect & Chatuchak & $\begin{array}{l}\text { Victory } \\
\text { Monument }\end{array}$ & Asoke \\
\hline $\begin{array}{l}\text { Transit time } \\
(\mathrm{min})\end{array}$ & $6-13$ & $3-18$ & $5-11$ \\
\hline $\begin{array}{l}\text { Transit distance } \\
(\mathrm{m})\end{array}$ & $15-75$ & $5-125$ & $20-110$ \\
\hline $\begin{array}{l}\text { Level of } \\
\text { crowdedness }\end{array}$ & Heavy & Heavy & Loose \\
\hline $\begin{array}{l}\text { Existing transit } \\
\text { facility }\end{array}$ & $\begin{array}{r}\text { Escalator, } \\
\text { elevator, bridge, } \\
\text { underground } \\
\text { metromall }\end{array}$ & $\begin{array}{r}\text { Escalator, } \\
\text { pedestrian } \\
\text { bridge }\end{array}$ & $\begin{array}{r}\text { Escalator, } \\
\text { elevator, } \\
\text { pedestrian } \\
\text { bridge, }\end{array}$ \\
$\begin{array}{l}\text { Idiosyncratic } \\
\text { Quality of transit }\end{array}$ & $\begin{array}{r}\text { Uneasy } \\
\text { particularly for } \\
\text { disabled person }\end{array}$ & $\begin{array}{r}\text { Uneasy } \\
\text { particularly for } \\
\text { disabled person } \\
\text { metromall }\end{array}$ & $\begin{array}{r}\text { Uneasy } \\
\text { particularly } \\
\text { for disabled } \\
\text { person }\end{array}$ \\
\hline
\end{tabular}

A brief description of these public transport modes in Bangkok is given in the following section, and their illustrations are given in Figure 1 .

\section{Formal and Informal Public Transport Modes in Bangkok}

The general characteristics of the public transport users in Bangkok are shown in Table 2.

Table 2 General Characteristics of Public Transport Users in Bangkok

\begin{tabular}{l|r|r}
\hline Attribute & \multicolumn{1}{|c|}{ Variables } & Percentage \\
\hline Age Group (year) & $5-15$ & 2 \\
\cline { 2 - 3 } & $16-20$ & 5 \\
\cline { 2 - 3 } & $21-30$ & 25 \\
\cline { 2 - 3 } & $31-40$ & 38 \\
\cline { 2 - 3 } & $41-50$ & 18 \\
\hline Gender & $>50$ & 12 \\
\hline Income Group & Male & 43 \\
\cline { 2 - 3 } (THB/month) & Female & 57 \\
\cline { 2 - 3 } & $15,001-30,000$ & 58 \\
\cline { 2 - 3 } & $30,001-50,000$ & 33 \\
\cline { 2 - 3 } & $>50,000$ & 5 \\
\hline Education Level & High school & 4 \\
\hline & and below & \\
\cline { 2 - 3 } & University & 32 \\
\cline { 2 - 3 } & Others & 7 \\
\hline
\end{tabular}

Table 2 shows that the public transport users are predominantly the lower income group. It is understood that the higher income group are mostly the private transport users that actually contributes to the traffic congestion in many parts of Bangkok. This is challenge for the transport planners and authorities to 
voluntarily drive the higher income group to shift to public transport, and at the same time, the improvement of public transport system in Bangkok is continuously carried out. It seems that the public transport network in Bangkok is being expanded to the neighboring province around Bangkok within Bangkok Metropolitan Region.

\subsection{Rail-based Transportation Systems}

The Bangkok Mass Transit System (BTS) or BTS Sky Train is the primary public transport in Bangkok. It is an elevated rail-based transportation system operated by BTS Group Holding Public Company Limited, covering $52 \mathrm{~km}$ of an elevated railway connecting 43 stations, and commenced in operation since 5 December 1999. The present daily ridership of BTS is about 650,000 passengers. It is consistently increasing since the beginning of the operation (BTS Skytrain, 2019). Metropolitan Rapid Transit (MRT) is an underground rail-based mass transportation system, with a total length of $45 \mathrm{~km}$, operated by Bangkok Expressway and Metro Public Company Limited (BEM) under a concession granted by Mass Rapid Authority of Thailand as the owner of MRT lines. MRT was commenced on 3 July 2004 (MRTA, 2019). Airport Link is an elevated railway on a viaduct over on the main eastern railway, with line length is $28.7 \mathrm{~km}$, operated by the consortium group of Charoen Pokphand Holding (CP), Ch. Karnchang PLC. (CK), Bangkok Expressway and Metro PLC. (BEM), Italian-Thai Development PLC. (ITD) and China Railway Construction Corporation Limited (CRCC). The owner is the State Railway of Thailand (SRT). It started in operation since 23 August 2010 (Airport Rail Link, 2019). The State Railway of Thailand also runs Eastern and Northern Lines which connects Bangkok Railway Station (Hualamphong) and some cities surrounding Bangkok Metropolitan, through some railway stations within Bangkok Metropolitan.

\subsection{Non-rail Transportation System}

Public Bus Transport: Various public buses are operating in 198 routes across the Bangkok Metropolitan Region which consists of Bangkok Metropolitan plus five adjacent provinces Nakhon Pathom, Pathumthani, Nonthaburi, Samut Prakan and Samut Sakhon (Bangkok Bus Routes, 2019; Wikipedia, 2019). They are basically belonging to two types: air conditioning and non-air conditioning buses. The bus fare varies according to distance and type of bus. The total length of bus routes in Bangkok Metropolitan Region is estimated about 4,950 kilometers with a total number of vehicle-kilometer travel in a year is predicted around 213,840,000, and the estimated person-kilometer traveled is about $4,276,800,000$ annually. Despite no data to prove the contribution of public bus transport in Bangkok Metropolitan, its role is expected significant in comparison to other modes of transport.

Water Transport (Boat): Water transports in Bangkok Metropolitan are mostly on Chaopraya River, the main river in Bangkok, and small rivers (khlongs) within Bangkok. The fare of small river boat is between 10-30 baht depending on the distance. The fare of the boat in Chaopraya river is 15 baht flat rate. The first pier of water transport in Chaopraya river is started in the downstream at Wat Rajsingkorn, Bangkolaem, and go to the upstream as far as Nonthaburi, with a distance of $20 \mathrm{~km}$. Meanwhile, for the small river transport in khlongs, the length of the line is about $120 \mathrm{~km}$ including the rivers transport for tourism purposes. The estimated person-kilometer traveled of water transport in Bangkok Metropolitan is about 70,560,000 annually. One of the advantages of using water transport in Bangkok is traffic jam free with reasonably low fare. However, the route is limited to the only area with suitable khlongs. The khlongs are normally maintenance-free since all the water depths in the khlongs are naturally maintained by sea level, and the erosion is small and controlled, thus the water depth is relatively stable for the whole year long.

Vans: There is the 10-seat capacity of van commuters from surrounding provinces to Bangkok and vice versa or within Bangkok itself. The fare is between 20-40 baht depending on the distance. However, for long distance vans, for instance, BangkokPattaya or Bangkok Huahin, the fare is between 200-400 baht. The person-kilometer traveled of the commuter van is estimated of about $115,200,000$ per year.

Taxi: This private-like public transport is the most obvious mode of transport in the cities including Bangkok Metropolitan because of flexible route and time as well as its convenience. The fare is certainly counted based on the distance. The estimated personkilometer traveled by Bangkok taxi is about 7,560,000,000 annually. This is certainly the largest contribution to public transport in Bangkok.

Tuk-tuk (another type of taxi): Tuk-tuk is another type of taxi and only available in Bangkok. This three-wheeled taxi can accommodate 3 passengers, with flexible routes and time. The fare is depending on the distance. The estimated person-kilometer traveled by tuk-tuk is about $388,500,000$ annually.

Songteaw (Pickup): This kind of transport is normally operated only in the city periphery where other formal transport modes do not reach this area. Songtaew can accommodate 14 passengers in two rows. The fare depends on the distance and the longest route is about $30 \mathrm{~km}$. The estimated person-kilometer traveled by Songtaew is $100,800,000$ per year.

Motorsai Krabchang (Motorbike Taxi): This is the most ubiquitous transport modes in Bangkok for their existence in many places in Bangkok, particularly near the bus stops, the mouth of alleys (sois). Their present makes public transportation in Bangkok is almost door-to-door transport service. Because of this overlap feature, it sometimes creates conflict among the drivers. The motorbike taxi normally serves only short distance travel e.g. $5 \mathrm{~km}$ maximum. The fare is between 20-80 baht depending on the distance. This is a traffic jam free taxi as motorbike is able to dodge the jam. The motorbike taxi can only accommodate 1 passenger per travel. The total estimated personkilometer traveled in Bangkok is about 1,670,400,000 annually. 

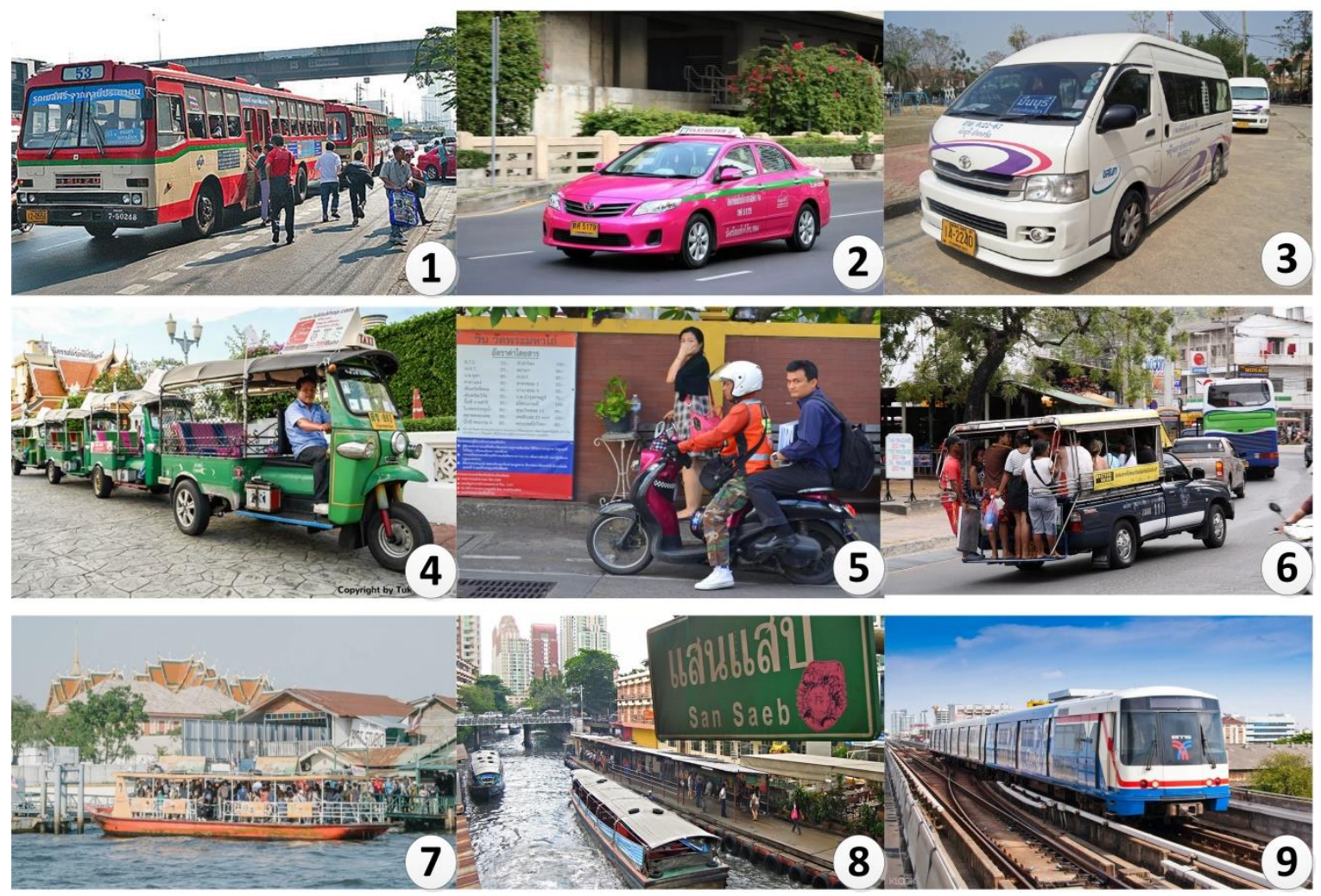

Figure 1: Various Types of Public Transport in Bangkok

[Note: (1) Bus (2) Taxi (3) Van (4) Tuktuk (5) Motorbike Taxi (6) Songtheaw (7) River Boat Chaopraya (8) Khlong Boat (9) BTS]

The above public transport modes in Bangkok are basically formal and informal public transport, which, in this study, their individual function will be assessed to deliver the transit process of the citizens in accomplishing their trip i.e. from origin to destination. Based on a study by Permana et al., (2018) and
Permana et al., (2015), the characteristics of formal and informal transport are shown in Table 3.

Table 3 Formal and Informal Public Transports Characteristic

\begin{tabular}{l|l|l}
\hline Aspect & Formal Public Transport & $\begin{array}{l}\text { Semi-formal and Informal Public } \\
\text { Transport }\end{array}$ \\
\hline Service Delivery & Designated, fixed and personalized routes & Personalized routes, adaptive \\
\hline Schedule & Semi-fixed, passenger-driven & Flexible, passenger-driven \\
\hline Reliability of service & Inconsistent to reliable depending on the type & Inconsistent to semi-reliable \\
\hline Vehicle Capacity & 4-seat to 500-seat passengers & 2-seat passengers \\
\hline Vehicle Type & Motorized & Motorized and non-motorized \\
\hline Ownership & Public and Private & Private, individual \\
\hline Market Perspective & Monopolist (public), Entrepreneurial (private) & Entrepreneurial, individual \\
\hline Labor & Semi-skilled & Semi- to non-skilled labor \\
\hline Organization & Bureaucracy, route associations & Individual, social associations \\
\hline User's social status & Low to medium income & Low to medium income \\
\hline Fare structure & Fixed, standardized & Variable, non-standardized \\
\hline \multicolumn{2}{|l}{ Source: AS Permana et al., (2018) }
\end{tabular}

In the case of formal, semi-formal, and informal public transports in Bangkok, the characteristics are almost the same as what is described in Table 3. By their respective features and advantages, along with transit infrastructure in Bangkok that connects these nine or ten transport modes, their seamlessness will be assessed by using the Modified Quantitative Gap Analysis (MQGA). The MQGA is used to evaluate the degree of importance of the 
elements of transit infrastructure, because of its suitability for assessing the gaps while avoiding subjective views.

\section{The seamlessness of the Transit Process}

Bangkok public transportation system has a potential feature to offer a seamless transit system (Chalermpong et al., 2018). A seamless transit system, in this case, is defined as a process of an intermodal transfer undertaken by either able or disable person without experiencing difficulties in accomplishing travel from origin to destination. While at a macro level a seamless transit requires the integration of the system for all transport modes, the users understand how to use it, standardization of fares for all transport modes that makes easy and comfortable for the travelers, and an integrated transit hub, at micro level it needs an easy and comfortable transfer pathways, shortest possible transit distance and transit time, accessible by either able or disable person, and availability of additional convenient facilities within the premise. A more detailed explanation of the micro level requirements of a seamless transit in case of Bangkok public transportation system is given in the subsequent section.

Integrated Transit Hub: The smooth interconnection of intermodal transport is a prerequisite of an integrated transit. The hub must be a point where some transport modes are connected, and make the interchange between transport modes by the travelers are possible, easy and comfortable. The interchange is preferably horizontal. However, if the horizontal interchange causes expanding hub, and this makes transit distance or transit time larger, a vertical interchange is then preferred, with a condition that accessibility by disabled persons must be in place. Combination of horizontal and vertical interchange most of the time cannot be avoided.
Easy and Comfortable Transfer Pathways: Easy transfer pathway determines the success of seamless transit. The travelers will have convenient experience in the transit process for their journeys. In a comfortable transfer, the pathways must be protected from sunlight and rainfall or other weather elements, to provide maximum comfort for the travelers. The pathways of intermodal transfer must be accessible by all including disables, elderly people, and disadvantages.

Transit Distance and Time: A transfer distance between transport modes must be as short as possible. This is to ensure an easy, comfort and in-time intermodal transfer for all types of travelers. The transfer process can be done as convenient as possible by travelers. Shorter transfer distance may minimize uncontrolled crowd during rush hours. With well-informed travelers about the hub, uncontrolled crowd with possible unwanted effect can be minimized.

Convenient Facilities: Various facilities within the premise of transit hubs such as convenient stores, information desk, ticket vending machines, toilets, and other facilities would make the transit experience more exciting. The consequence of these facilities is that the hub must be sufficiently large, which is to some extent, difficult to provide unless underground.

The above requirements will be tested in selected transit hubs of formal transport modes i.e. BTS, MRT, Public Bus, Taxi and Private Transport; and informal transport modes i.e. motorbike taxi. The selected transit hubs are shown in Table 4. The selection of hubs is based on the number of transportation modes meet in the hubs. The only hub with more than three primary transport modes has been selected. An Analytic Hierarchy Process method is used to analyze the seamlessness, and the users' perception is employed to evaluate the degree of seamlessness based on their experience.

Table 4 Selected Transit Hubs

\begin{tabular}{l|l|l}
\hline No & Hub & Intermodal Transport \\
\hline 1 & Mochit-Chatuchak Park & BTS, MRT, Public Bus, Taxi, Motorbike Taxi \\
\hline 2 & Phayathai & BTS, ARL, SRTET, Public Bus, Taxi, Motorbike Taxi \\
\hline 3 & Makkasan-Petchburi & MRT, ARL, SRTET, Public Bus, Taxi, Motorbike Taxi \\
\hline 4 & Sukhumvit-Asoke & MRT, BTS, Public Bus, Taxi, Motorbike Taxi \\
\hline 5 & Saladaeng-Silom & MRT, BTS, Public Bus, Taxi, Motorbike Taxi \\
\hline 6 & Saphan Taksin-Sathorn & BTS, River Boat, Public Bus, Taxi, Motorbike Taxi, Songteaw \\
\hline
\end{tabular}

Six transit hubs were selected among 17 possible hubs to cover as much as a possible number of formal, semi-formal, and informal transport modes. The selected hubs are shown in Figure 2. The features of each hub are explained in the subsequent sections. 


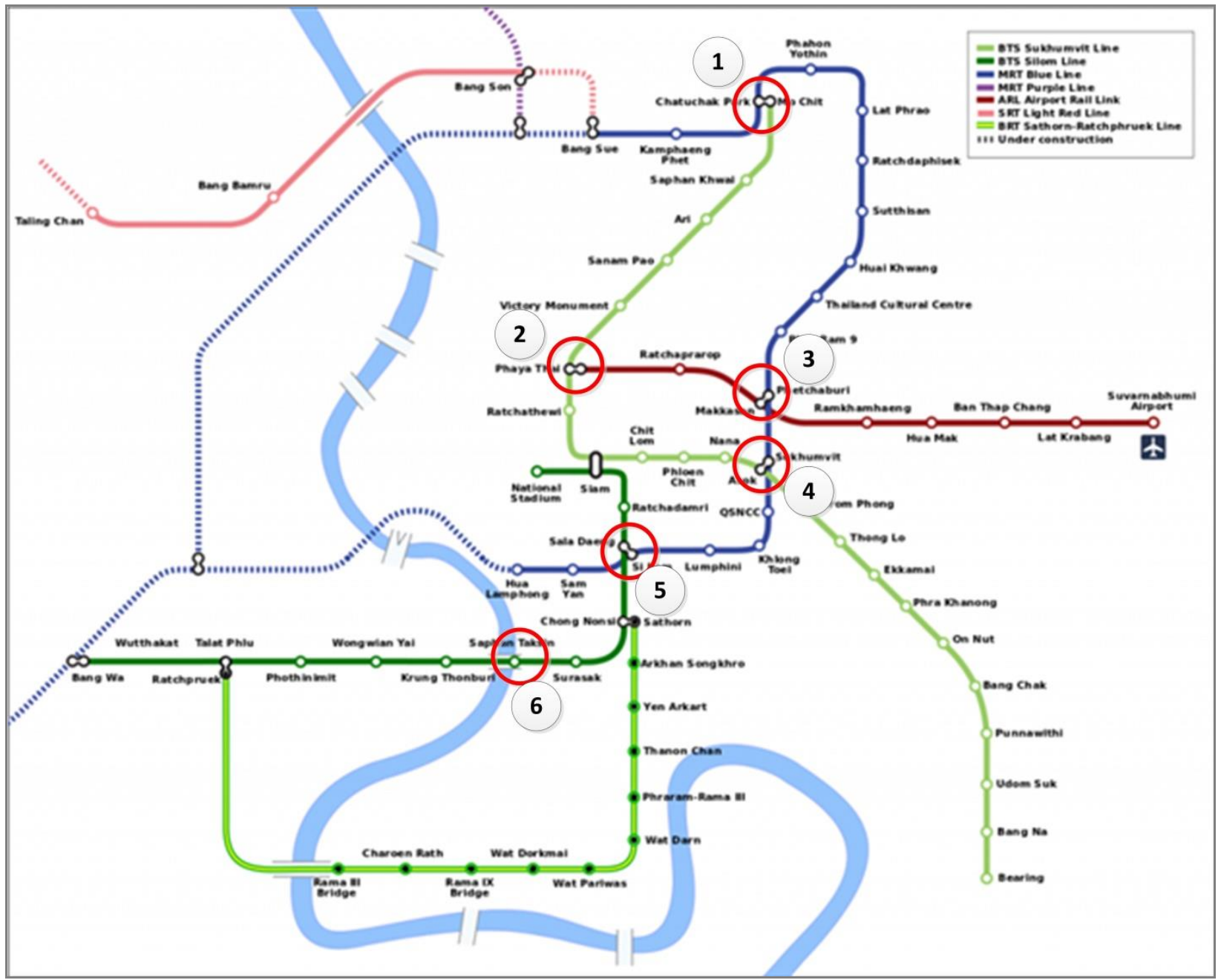

Figure 2 Selected Transit Hubs in Bangkok

\section{Selected Transit Hubs}

Among 17 transit hubs within Bangkok Metropolitan, which are qualified for assessment, 6 transit hubs have been selected for assessment as shown in Table 2. During the course of discussion in this section, there is a rating system proposed by the authors on the six variables of the intermodal transit, based on the perceptions of the transit hub users. These variables include integration of the transit, easiness of the transit process, comfort during the transit, transit distance, transit time, and convenient facilities. The scales of these variables are ranging from 1 (worse) to 5 (excellent), with the following explanation:

For the qualitative arguments such as integration of the transit, easiness of the transit process, comfort during the transit, and convenient facilities, the transit hub and public transport users, the standardized perception of the users is applied, which is $\mu+2 \sigma$ is calculated as excellent (5) and $\mu-2 \sigma$ as worse (1), and $\mu$ itself is treated as neutral (3). Then based on these values, the rating is given.
For quantitative argument such as transit distance and transit time, the following discrete values are applied:

- The score is 5 (Excellent) if distance 0-25 meters, or transit time 0-1 minutes

- The score is 4, if distance: 26-50 meters, and t: 1-2 minutes

- The score is 3, if distance: 51-100 meters, and t:2-5 minutes

- The score is 2, if distance: 101-200 meters, and t:5-10 minutes

- The score is 1 (worse), if distance: $>200$ meters, and $\mathrm{t}>10$ minutes.

There is, of course, no definite formula to determine these subjective arguments, but the most important message of this rating is that the reader would be able to imagine either the easiness or difficulty in undertaking the transit process, without necessary to carry out the transit by their own. 


\subsection{Chatuchak-Mochit Transit $\mathrm{Hub}$}

Physical Feature: Chatuchak and Mochit transit hub is considered as one of the largest hubs in Bangkok as Bangkok Mass Transit System (BTS) - the Skytrain, Bangkok Mass Rapid Transit (MRT), Bus, Taxi, Van, Motorbike Taxi, and private cars (Park and Ride at Mochit) are jointly forming a transit hub in this area. In the future, the State Railway of Thailand Northern Track (SRTNT) will also join the hub, although the connection is a little bit farther than 500 meters. The interconnection in the Chatuchak-Mochit hub is graphically shown in Figure 3.

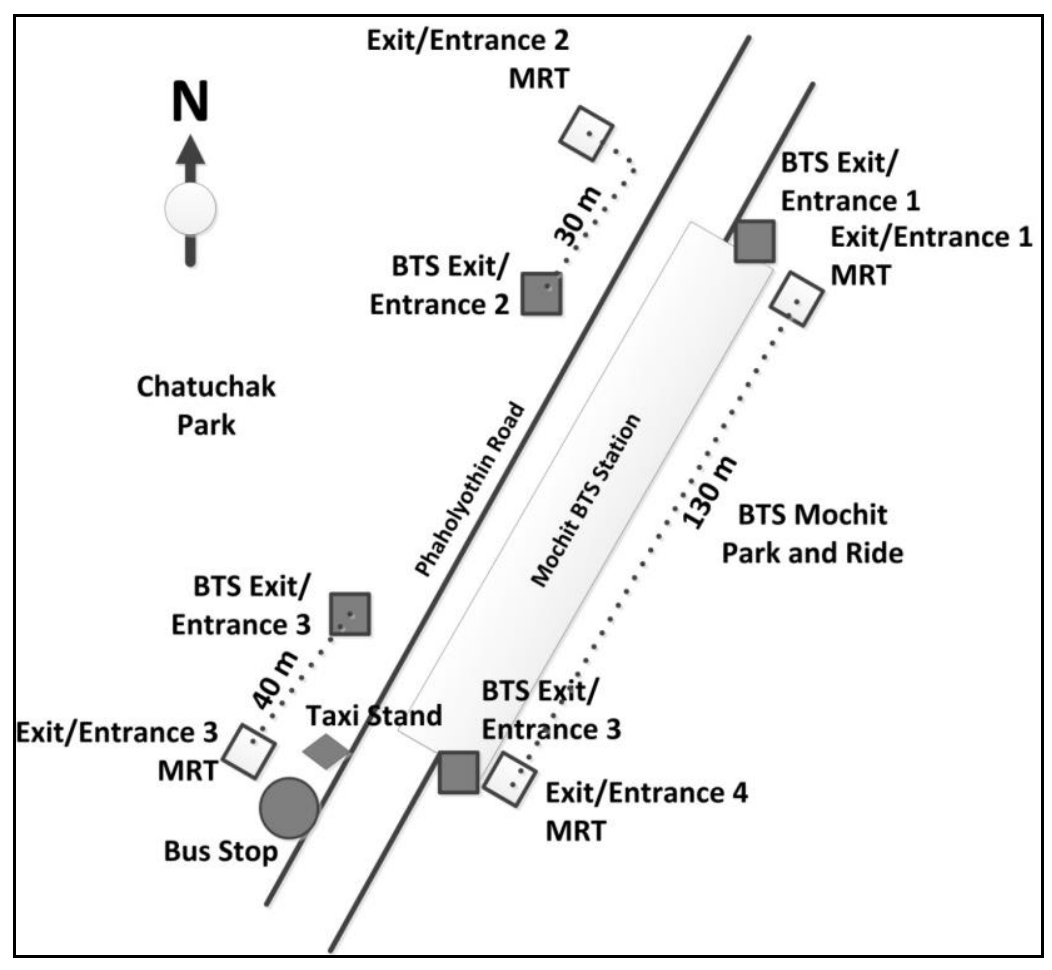

Figure 3 Mochit-Chatuchak Hub

(Transport Modes: BTS, MRT, Bus, Taxi, Motorbike Taxi, Park and Ride)

From the observation in all MRT stations, the facilities for in and out of disabled people from the very first entrance up until entering the train, the disabled people will be able to travel independently i.e. without the bits of help from others by using MRT. The elevator, which is provided a convenient ramp, is available through ticketing service and the entrance of the train. A different situation exists in the BTS stations. Only a few BTS stations are provided an elevator for disable person. Not to mention the public bus and other transport modes in Bangkok. This condition brings to a situation that public transport in Bangkok is not at all friendly for a disabled person, even though the disabled persons are traveling with the help of others. This fact will be proven by using field observations and opinion from the users.

Transit Process: Time required for transit from MRT (exit from the train) to BTS (entering the train), according to several times survey, in Chatuchak-Mochit transit hub, is in average about 16.5 minutes. This includes the waiting time of the BTS. The pathway within the premise of MRT is comfortable with facilities of Metro Mall, ATM, and food and beverage shops. The signage is seemingly also sufficient to ease where to go. However, this is not for the first time travelers or the ones who do not now the aboveground situation i.e. the locations of the exits. Two to five minutes additional times will be required if one goes out through the wrong exit since each exit was designed for different directions.

The survey results on four qualities of a transit hub namely integration, easy and comfortable transfer pathways, transit distance and time, and, convenient facilities at Chatuchak-Mochit Transit Hub are summarized in Table 5. The surveys were carried out by assessing every possible transit process by the users, particularly in two intermodal transfers, and vice versa. The distance within the premise was approximated by a number of constant steps, since direct measurement by using a measuring device will need special permission and sufficient surveyors. The time is however measured by using stop watch. 
Table 5 Summary of the Transit Process Survey in Chatuchak-Mochit Transit Hub

\begin{tabular}{|c|c|c|c|}
\hline Transit Process & Quantity of Transit & Quality of Transit & $\begin{array}{l}\text { Own Rating } \\
\text { (1:worse, 5:excellent) }\end{array}$ \\
\hline MRT to BTS & $\begin{array}{l}\text { - Time required (gate-to-gate): } 8 \\
\text { minutes } \\
\text { - Vertical Distance: } 20 \mathrm{~m} \text { by } \\
\text { escalator+10m manual stair } \\
\text { - Horizontal Distance: } 120 \mathrm{~m}\end{array}$ & $\begin{array}{l}\text { - } \\
\text { - } \text { Vlevator available at MRT } \\
\text { - Pathways: within MRT: excellent, } \\
\text { within BTS: good, in between: bad } \\
\text { i.e. uneven surface, crowd } \\
\text { - Disable: not possible }\end{array}$ & $\begin{array}{l}\text { Integration: } 2 \\
\text { Easiness: } 3 \\
\text { Comfort: } 3 \\
\text { Transit distance: } 3 \\
\text { Transit time: } 3 \\
\text { Convenient facilities: } 4\end{array}$ \\
\hline $\begin{array}{l}\text { BTS to } \\
\text { Bus/Taxi/Motorbike } \\
\text { Taxi }\end{array}$ & $\begin{array}{l}\text { - Time required: } 6 \text { minutes } \\
\text { - Vertical distance: } 10 \mathrm{~m} \text { stair } \\
\text { - Horizontal Distance: } 50 \mathrm{~m}\end{array}$ & $\begin{array}{l}\text { - Elevator available at BTS } \\
\text { - Vertical transport: stair } \\
\text { - Pathway within BTS: good, in bus } \\
\text { - } \text { platform: bad, crowd, disorder } \\
\end{array}$ & $\begin{array}{l}\text { Integration: } 2 \\
\text { Easiness: } 2 \\
\text { Comfort: } 2 \\
\text { Transit distance: } 3 \\
\text { Transit time: } 3 \\
\text { Convenient facilities: } 2 \\
\end{array}$ \\
\hline $\begin{array}{l}\text { MRT to } \\
\text { Bus/Taxi/Motorbike } \\
\text { Taxi }\end{array}$ & $\begin{array}{l}\text { Time required: } 8-15 \text { minutes } \\
\text { (depending on the exit) } \\
\text { - Vertical distance: } 20-40 \mathrm{~m} \\
\text { (depending on the exit) } \\
\text { - Horizontal Distance: } 80-150 \mathrm{~m} \\
\text { (depending on the exit) }\end{array}$ & $\begin{array}{l}\text { Vertical transport: } \\
\text { escalator/elevator } \\
\text { - Pathways: within MRT: excellent, } \\
\text { pathways to bus/taxi/motorbike } \\
\text { stands: bad i.e. uneven surface, } \\
\text { crowd } \\
\text { - Disable: not possible }\end{array}$ & $\begin{array}{l}\text { Integration: } 2 \\
\text { Easiness: } 2 \\
\text { Comfort: } 2 \\
\text { Transit distance: } 3 \\
\text { Transit time: } 3 \\
\text { Convenient facilities: } 2\end{array}$ \\
\hline
\end{tabular}

\subsection{Phayathai Transit Hub}

Physical Feature: Phayathai transit hub connects BTS, Airport Rail Link (ARL), State Railway of Thailand Eastern Track (SRTET, which runs from Bangkok to Aranyaprathet), Bus, Taxi, and Motorbike Taxi. An elevator is available in the ARL but unavailable in the BTS. In terms of horizontal distance, the hub offers a within-walking-distance quality, as exhibited by the closeness of ARL Phayathai Station, BTS Phayathai Station, Bus stands, Motorbike stands and Taxi, which the farthest is around 70 meters. The closest transit is between SRTET and bus, which is about 10 meters. One of the main defects of this hub is the presence of rudimentary train station of the SRTET in Phayathai, which is not convenient for the travelers. However, this hub is unfriendly to disabled people. The hub is schematically shown in Figure 4.

The gate of BTS and ARL at Phayathai Hub is practically at the same floor, and it is therefore convenient to transfer in both directions. Transfer from BTS to bus through CP Tower is also close. The only transfer from BTS to south-bound bus is little bit far with about 150 meters away from the BTS exit.

Transit Process: The shortest transit distance in this hub is from SRTET to Bus or Taxi or Motorbike Taxi with just a few meters away. But with respect to comfort, this part does not offer any comfort for the travelers. The most comfortable transit is probably between BTS and ARL vice versa, because of both platform shares the same premise and floor (as exhibited in Figure $5)$. The most uncomfortable transit happens when a traveler from Suvarnabhumi Airport with luggage who getting-off at Phayathai (the terminal station) to bus or taxi. The possible barriers are bringing the luggage through stair or grabbing the luggage through the uneven surface of pathways after exiting from the BTS or ARL stations. The summary of transit process is given in Table 6. 


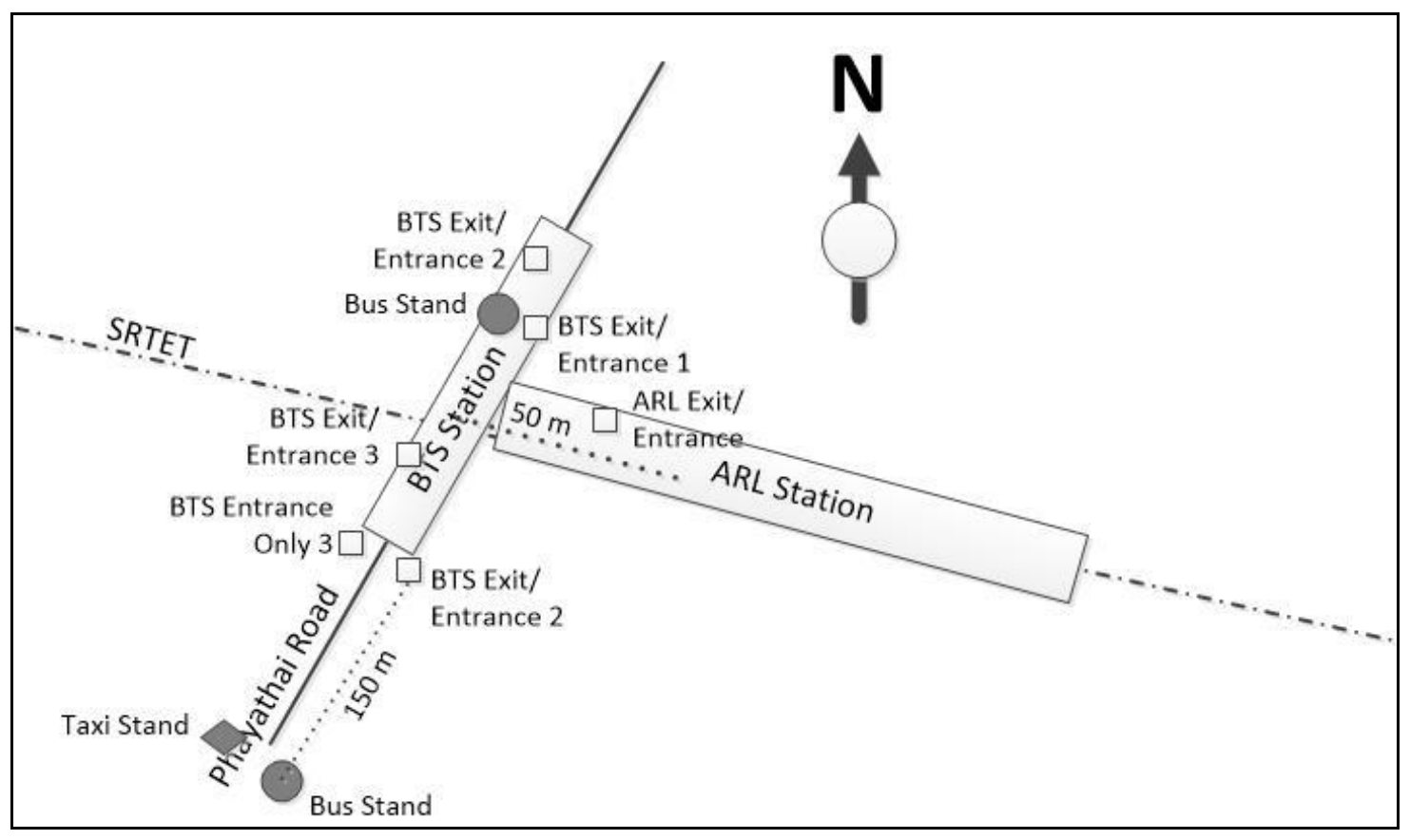

Figure 4 Phayathai Hub

(Transport Modes: BTS, ARL, SRTET, Bus, Taxi, Motorbike Taxi)

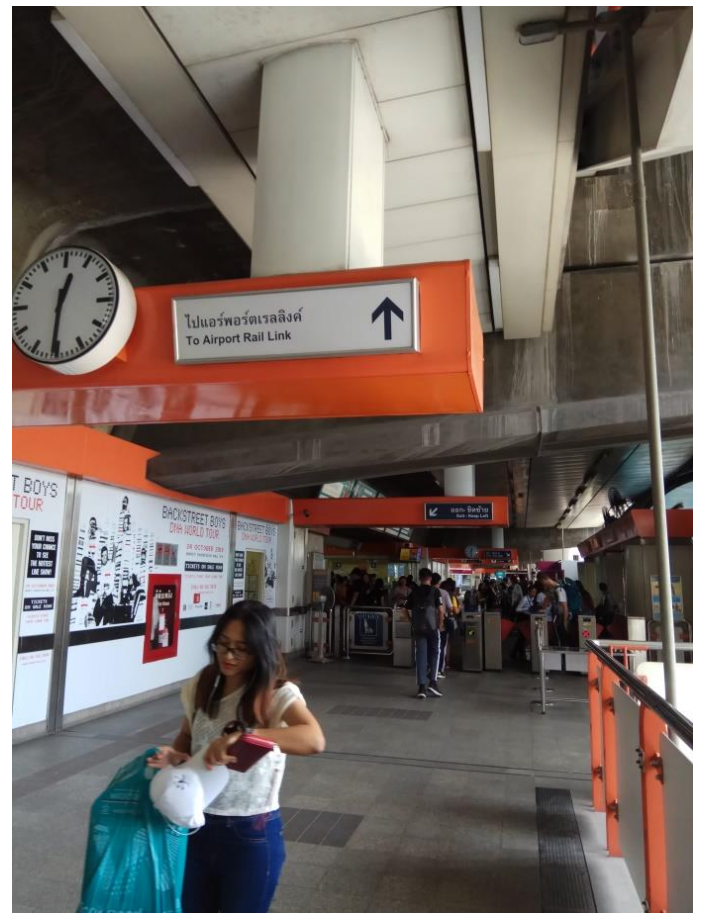

Figure 5 Pathway to ARL from BTS at Phayathai

\subsection{Makkasan-Petchburi Transit Hub}

Physical Feature: The transport modes involved in the transit process in this hub are ARL, SRTET, MRT, Bus, Taxi, and Motorbike Taxi. A 100-meter length of Sky Bridge connects MRT Makkasan ARL station and MRT exit/entrance, and it makes about 150 meters the total distance of both. This hub is not friendly to disable even though MRT and ARL provide elevators, but both are separated by a busy junction, which is impossible to cross by disabled people. On the other hand, the disabled people are not possible to go through the Sky Bridge as the end part of the Sky Bridge at MRT entrance is not equipped with an elevator. The hub is schematically exhibited in Figure 6.

Transit Process: the transit can be done among MRT, ARL, SRTET, Bus, Taxi, and Motorbike Taxi. However, this transit process is, to some extent, neither for disable people nor disadvantages i.e. elderly. However, for certain travel, for example, from any MRT station to the Suvarnabhumi Airport, disabled people will be able to travel alone, by stopping at Asoke station, then exit through the available elevator and connect through Sky Bridge to ARL and continue to the Airport. For any other destinations, the disabled people will not be able to travel alone without helps from any other people. The process of transit is summarized in Table 7. 
Table 6 Summary of the Transit Process Survey in Phayathai Transit Hub

\begin{tabular}{|c|c|c|c|}
\hline Transit Process & Quantity of Transit & Quality of Transit & $\begin{array}{l}\text { Own Rating } \\
\text { (1:worse, 5:excellent) }\end{array}$ \\
\hline MRT to ARL & $\begin{array}{l}\text { - Time required (gate-to-gate): } 3 \\
\text { minutes } \\
\text { - Vertical Distance: } 10 \mathrm{~m} \text { by } \\
\text { escalator+10m manual stair } \\
\text { - Horizontal Distance: } 30 \mathrm{~m}\end{array}$ & $\begin{array}{l}\text { - Elevator available at ARL } \\
\text { - Vertical transport: escalator } \\
\text { - Pathways: within MRT: good, } \\
\text { within ARL: good, in between: } \\
\text { good } \\
\text { - Disable: not possible }\end{array}$ & $\begin{array}{l}\text { Integration: } 4 \\
\text { Easiness: } 4 \\
\text { Comfort: } 3 \\
\text { Transit distance: } 4 \\
\text { Transit time: } 4 \\
\text { Convenient facilities: } 3\end{array}$ \\
\hline $\begin{array}{l}\text { BTS to } \\
\text { Bus/Taxi/Motorbike } \\
\text { Taxi }\end{array}$ & $\begin{array}{l}\text { - Time required: } 3 \text { minutes } \\
\text { - Vertical distance: } 10 \mathrm{~m} \text { stair } \\
\text { - Horizontal Distance: } 20 \mathrm{~m}\end{array}$ & $\begin{array}{l}\text { - Escalator available at BTS (one } \\
\text { side, entrance only) } \\
\text { - Vertical transport: stair } \\
\text { - Pathway within BTS: good, in bus } \\
\text { platform: bad, crowd, disorder } \\
\text { - Disable: not possible }\end{array}$ & $\begin{array}{l}\text { Integration: } 3 \\
\text { Easiness: } 2 \\
\text { Comfort: } 2 \\
\text { Transit distance: } 3 \\
\text { Transit time: } 3 \\
\text { Convenient facilities: } 3\end{array}$ \\
\hline $\begin{array}{l}\text { SRTET to } \\
\text { Bus/Taxi/Motorbike } \\
\text { Taxi }\end{array}$ & $\begin{array}{l}\text { - Time required: } 2 \text { minutes } \\
\text { - Vertical distance: } 0 \\
\text { - Horizontal Distance: } 10 \mathrm{~m}\end{array}$ & $\begin{array}{l}\text { - Vertical transport: none } \\
\text { - Pathways: worse } \\
\text { - Disable: not possible }\end{array}$ & $\begin{array}{l}\text { Integration: } 3 \\
\text { Easiness: } 2 \\
\text { Comfort: } 2 \\
\text { Transit distance: } 4 \\
\text { Transit time: } 4 \\
\text { Convenient facilities: } 3\end{array}$ \\
\hline
\end{tabular}

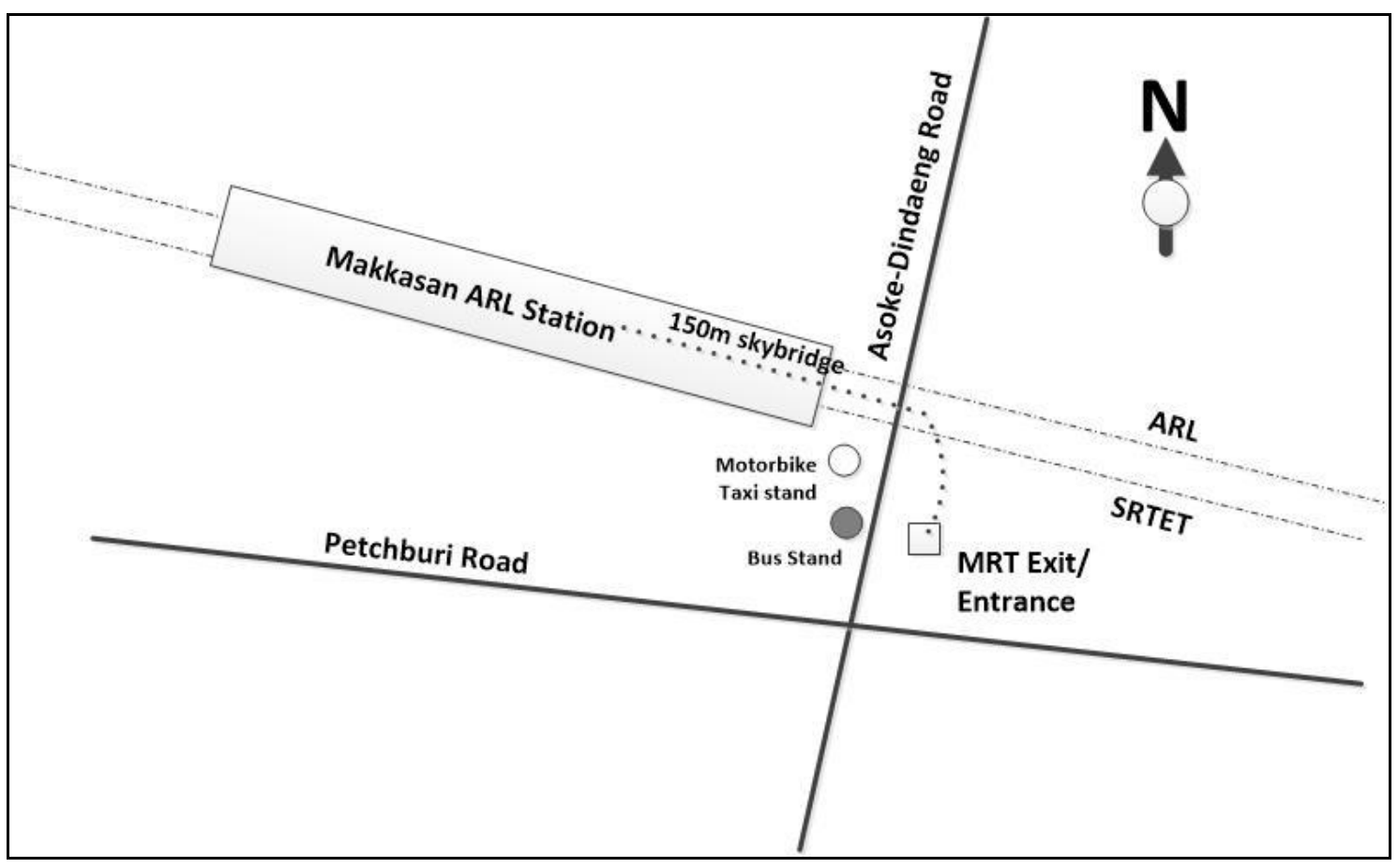

Figure 6 Makkasan-Petchburi Hub

(Transport Modes: ARL, SRTET, MRT, Bus, Taxi, Motorbike Taxi) 
Table 7 Summary of the Transit Process Survey in Makkasan-Petchburi Transit Hub

\begin{tabular}{|c|c|c|c|}
\hline Transit Process & Quantity of Transit & Quality of Transit & $\begin{array}{l}\text { Own Rating } \\
\text { (1:worse, 5:excellent) }\end{array}$ \\
\hline MRT to ARL & $\begin{array}{l}\text { - Time required (gate-to-gate): } 8 \\
\text { minutes } \\
\text { - Vertical Distance: } 30 \mathrm{~m} \text { by } \\
\text { escalator } \\
\text { - Horizontal Distance: } 150 \mathrm{~m}\end{array}$ & $\begin{array}{l}\text { - Elevator available at ARL } \\
\text { - Vertical transport: escalator } \\
\text { - Pathways: within MRT: good, } \\
\text { within ARL: good, in between: } \\
\text { good (Sky Bridge) } \\
\text { - Disable: not possible } \\
\end{array}$ & $\begin{array}{l}\text { Integration: } 3 \\
\text { Easiness: } 3 \\
\text { Comfort: } 3 \\
\text { Transit distance: } 2 \\
\text { Transit time: } 2 \\
\text { Convenient facilities: } 2\end{array}$ \\
\hline $\begin{array}{l}\text { ARL to } \\
\text { Bus/Taxi/Motorbike } \\
\text { Taxi }\end{array}$ & $\begin{array}{l}\text { - Time required: } 5 \text { minutes } \\
\text { - Vertical distance: } 10 \mathrm{~m} \text { stair } \\
\text { - Horizontal Distance: } 30 \mathrm{~m}\end{array}$ & $\begin{array}{l}\text { - Escalator available at ARL (going } \\
\text { up only) } \\
\text { - Vertical transport: stair } \\
\text { - Pathway within ARL: good, in } \\
\text { between: busy traffic, bus } \\
\text { platform: bad, disorder } \\
\text { - Disable: not possible }\end{array}$ & $\begin{array}{l}\text { Integration: } 2 \\
\text { Easiness: } 1 \\
\text { Comfort: } 1 \\
\text { Transit distance: } 2 \\
\text { Transit time: } 2 \\
\text { Convenient facilities: } 2\end{array}$ \\
\hline $\begin{array}{l}\text { MRT to } \\
\text { Bus/Taxi/Motorbike } \\
\text { Taxi/Park and Ride }\end{array}$ & $\begin{array}{l}\text { - Time required: } 5 \text { minutes } \\
\text { - Vertical distance: } 20 \mathrm{~m} \text { by } \\
\text { elevator } \\
\text { - Horizontal Distance: } 20 \mathrm{~m}\end{array}$ & $\begin{array}{l}\text { - Vertical transport: elevator } \\
\text { - Pathways: busy traffic } \\
\text { - Disable: not possible }\end{array}$ & $\begin{array}{l}\text { Integration: } 1 \\
\text { Easiness: } 1 \\
\text { Comfort: } 1 \\
\text { Transit distance: } 2 \\
\text { Transit time: } 2 \\
\text { Convenient facilities: } 2\end{array}$ \\
\hline
\end{tabular}

\subsection{Sukhumvit-Asoke Transit Hub}

Physical Feature: This hub connects BTS, MRT, Bus, Taxi, and Motorbike Taxi. Motorbike taxi is practically available in most of the alley's mouths in Bangkok. This hub provides the same feature with other hubs for disabled people in terms of unfriendliness. MRT, which comes more recent than BTS in Bangkok, provides a friendlier feature for disable persons. The elevator and ramps for in and out of the disabled travelers are in place. However, only a few BTS stations provide facilities for disabled people. The hub is schematically shown in Figure 7.

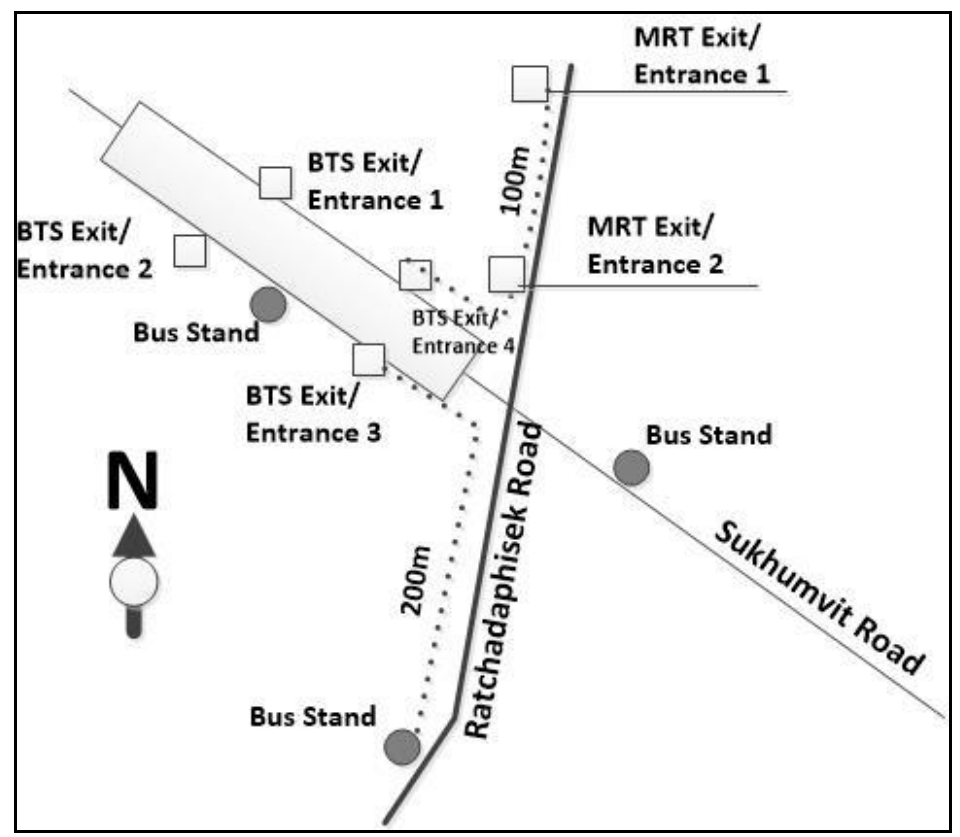

Figure 7 Sukhumvit-Asoke Hub

(Transport Modes: BTS, MRT, Bus, Taxi, Motorbike Taxi) 
Table 8 Summary of the Transit Process Survey in Sukhumvit-Asoke Transit Hub

\begin{tabular}{|c|c|c|c|}
\hline Transit Process & Quantity of Transit & Quality of Transit & $\begin{array}{l}\text { Own Rating } \\
\text { (1:worse, 5:excellent) }\end{array}$ \\
\hline MRT to BTS & $\begin{array}{l}\text { - Time required (gate-to-gate): } 3 \\
\text { minutes } \\
\text { - Vertical Distance: } 20 \mathrm{~m} \text { by } \\
\text { escalator+10 meter stair } \\
\text { - Horizontal Distance: } 5 \mathrm{~m}\end{array}$ & $\begin{array}{l}\text { - } \\
\text { Elevator available at MRT } \\
\text { - Vertical transport: escalator and } \\
\text { stair } \\
\text { - Pathways: within MRT: good, } \\
\text { within BTS: good, in between: } \\
\text { bad } \\
\text { - Disable: not possible }\end{array}$ & $\begin{array}{l}\text { Integration: } 2 \\
\text { Easiness: } 3 \\
\text { Comfort: } 2 \\
\text { Transit distance: } 3 \\
\text { Transit time: } 3 \\
\text { Convenient facilities: } 3\end{array}$ \\
\hline $\begin{array}{l}\text { BTS to } \\
\text { Bus/Taxi/Motorbike } \\
\text { Taxi }\end{array}$ & $\begin{array}{ll}\text { - } & \text { Time required: } 3 \text { minutes } \\
\text { - } & \text { Vertical distance: } 10 \mathrm{~m} \text { stair } \\
\text { - } & \text { Horizontal Distance: } 30 \mathrm{~m}\end{array}$ & $\begin{array}{l}\text { - Vertical transport: stair } \\
\text { - Pathway within BTS: good, in } \\
\text { between: bad, at platform: bad, } \\
\text { disorder } \\
\text { - Disable: not possible }\end{array}$ & $\begin{array}{l}\text { Integration: } 3 \\
\text { Easiness: } 3 \\
\text { Comfort: } 2 \\
\text { Transit distance: } 3 \\
\text { Transit time: } 3 \\
\text { Convenient facilities: } 3\end{array}$ \\
\hline $\begin{array}{l}\text { MRT to } \\
\text { Bus/Taxi/Motorbike } \\
\text { Taxi/Park and Ride }\end{array}$ & $\begin{array}{l}\text { Time required: 5-10 minutes } \\
\text { (depending on exit/entrance } \\
\text { location) } \\
\text { - Vertical distance: } 20-30 \mathrm{~m} \text { by } \\
\text { elevator and stair (depending } \\
\text { on exit/entrance) } \\
\text { - Horizontal Distance: } 20-80 \mathrm{~m} \\
\text { (depending on exit/entrance) }\end{array}$ & $\begin{array}{l}\text { - Vertical transport: elevator and } \\
\text { stair } \\
\text { - Pathways: within MRT: good, in } \\
\text { between: bad, in platform: bad } \\
\text { - Disable: not possible }\end{array}$ & $\begin{array}{l}\text { Integration: } 2 \\
\text { Easiness: } 2 \\
\text { Comfort: } 2 \\
\text { Transit distance: } 2 \\
\text { Transit time: } 2 \\
\text { Convenient facilities: } 2\end{array}$ \\
\hline
\end{tabular}

Transit Process: Transit can be done among these five transport modes, particularly between BTS and MRT and between BTS or MRT with other transport modes. Transfer from BTS to bus especially at Sukhumvit road seems the easiest one as the bus stand is right below the BTS station. To some extent, transfer between BTS and MRT (for a particular exit/entrance) as one exit of the BTS is right in front of one MRT entrance. The summary of transit process is shown in Table 8 .

\subsection{Saladaeng-Silom Transit Hub}

Physical Feature: This hub features the connection of BTS, MRT, Bus, Taxi, and Motorbike Taxi. This hub does not support people with disability. Survey shows that transit at this hub from BTS to MRT requires 8 minutes. The distance between the exit/entrance of BTS and exit/entrance of MRT is about 150 meters. The BTS Saladaeng Station is a bit far from the junction of Rama IV-Ratchdamri-Silom Roads. The walkway from BTS to MRT is a short Sky Bridge and down to the entrance of BTS by using stair. The schematic situation of Hub is seen in Figure 8.

Transit Process: The shortest transit at this hub is between BTS and bus bound for southwest direction, as the bus stand is below the premise of BTS Saladaeng Station. The longest transit occurs when a BTS traveler would change the transport mode to a bus bound for Hualamphong (west direction). He/she must walk for about 250 meters with uncomfortable pathways particularly after get out from BTS exit. The walkway is not so convenient for walking children or loads. With respect to integrated-ness, the hub is poorly integrated. This feature is most probably because of timely-separated planning with different planners and implementers.

The summary of result of transit survey at Saladaeng-Silom Transit Hub is presented in Table 9. The survey was undertaken at non-peak hours around 10-11am.

\subsection{Saphan Thaksin-Sathorn Transit Hub}

Physical Feature: This hub is actually not that important. However, it is included in the assessment as it needs to include a different kind of transport modes. Saphan Thaksin-Sathorn hub connects mainly BTS at Saphan Thaksin station and Boat River Pier of Sathorn with the additional bus, taxi, motorbike taxi, and songteaw. Survey reveals that taxi and motorbike taxi is available anywhere particularly in any transits and junctions. These transport modes have made intermodal transits easier, even though it is still far to serve the convenience of disabled people. This hub is shown in Figure 9. 


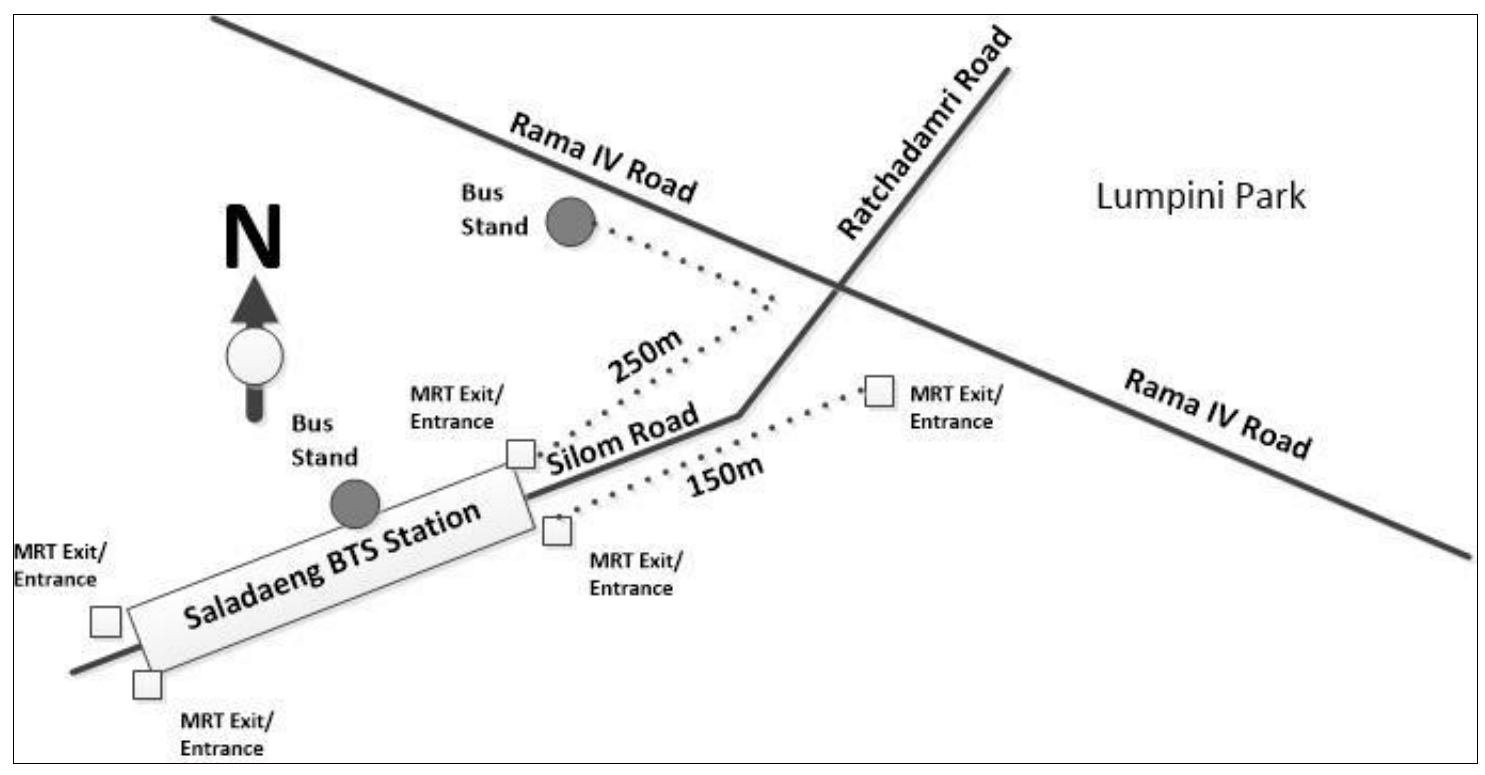

Figure 8 Silom-Saladaeng Hub

(Transport Modes: BTS, MRT, Bus, Taxi, Motorbike Taxi)

Table 9 Summary of the Transit Process Survey in Saladaeng-Silom Transit Hub

\begin{tabular}{|c|c|c|c|}
\hline Transit Process & Quantity of Transit & Quality of Transit & $\begin{array}{l}\text { Own Rating } \\
\text { (1:worse, 5:excellent) }\end{array}$ \\
\hline MRT to BTS & $\begin{array}{l}\text { - Time required (gate-to-gate): } 3 \\
\text { minutes } \\
\text { - Vertical Distance: } 20 \mathrm{~m} \text { by } \\
\text { escalator+10 meter stair } \\
\text { - Horizontal Distance: } 150 \mathrm{~m}\end{array}$ & $\begin{array}{l}\text { - Elevator available at MRT } \\
\text { - Vertical transport: escalator and } \\
\text { stair } \\
\text { - Pathways: within MRT: good, } \\
\text { within BTS: good, in between: } \\
\text { bad } \\
\text { - Disable: not possible }\end{array}$ & $\begin{array}{l}\text { Integration: } 2 \\
\text { Easiness: } 2 \\
\text { Comfort: } 2 \\
\text { Transit distance: } 2 \\
\text { Transit time: } 2 \\
\text { Convenient facilities: } 3\end{array}$ \\
\hline $\begin{array}{l}\text { BTS to } \\
\text { Bus/Taxi/Motorbike } \\
\text { Taxi }\end{array}$ & $\begin{array}{l}\text { - Time required: } 5 \text { minutes } \\
\text { - Vertical distance: } 10 \mathrm{~m} \text { stair } \\
\text { - Horizontal Distance: } 50 \mathrm{~m}\end{array}$ & $\begin{array}{l}\text { - Vertical transport: stair } \\
\text { - Pathway within BTS: good, in } \\
\text { between: bad, at platform: bad, } \\
\text { disorder } \\
\text { - Disable: not possible }\end{array}$ & $\begin{array}{l}\text { Integration: } 2 \\
\text { Easiness: } 2 \\
\text { Comfort: } 2 \\
\text { Transit distance: } 3 \\
\text { Transit time: } 3 \\
\text { Convenient facilities: } 3 \\
\end{array}$ \\
\hline $\begin{array}{l}\text { MRT to } \\
\text { Bus/Taxi/Motorbike } \\
\text { Taxi/Park and Ride }\end{array}$ & $\begin{array}{l}\text { - Time required: 3-10 minutes } \\
\text { (depending on exit/entrance } \\
\text { location) } \\
\text { - Vertical distance: } 20 \mathrm{~m} \text { by } \\
\text { elevator } \\
\text { - Horizontal Distance: } 20-80 \mathrm{~m} \\
\text { (depending on exit/entrance) }\end{array}$ & $\begin{array}{l}\text { - Vertical transport: escalator } \\
\text { - Pathways: within MRT: good, in } \\
\text { between: bad, in platform: bad } \\
\text { - Disable: not possible }\end{array}$ & $\begin{array}{l}\text { Integration: } 2 \\
\text { Easiness: } 2 \\
\text { Comfort: } 2 \\
\text { Transit distance: } 2 \\
\text { Transit time: } 2 \\
\text { Convenient facilities: } 2\end{array}$ \\
\hline
\end{tabular}




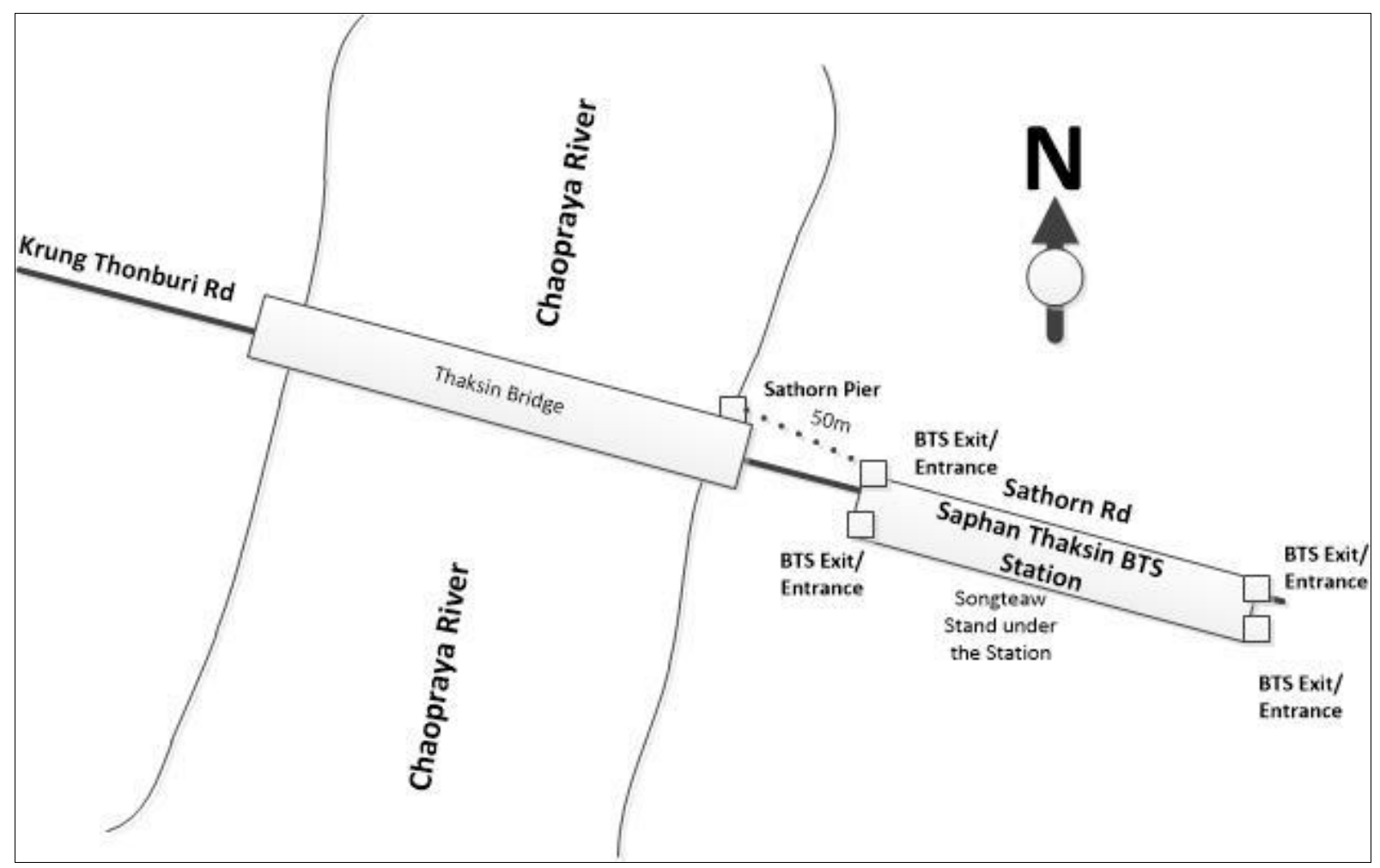

Figure 9 Saphan Thaksin Hub

(Transport Modes: BTS, MRT, Bus, Taxi, Motorbike Taxi, Songteaw)

Table 10 Summary of the Transit Process Survey in Saphan Thaksin-Sathorn Hub

\begin{tabular}{|c|c|c|c|}
\hline Transit Process & Quantity of Transit & Quality of Transit & $\begin{array}{l}\text { Own Rating } \\
\text { (1:worse, 5:excellent) }\end{array}$ \\
\hline BTS to River Boat & $\begin{array}{l}\text { - Time required: } 5-10 \text { minutes } \\
\text { (depending on the exit) } \\
\text { - Vertical Distance: } 10 \mathrm{~m} \text { by stair } \\
\text { - Horizontal Distance: } 50-150 \mathrm{~m} \\
\text { (depending on the exit) }\end{array}$ & $\begin{array}{l}\text { - Vertical transport: stair } \\
\text { - Pathways: within BTS: good, in } \\
\text { between: bad } \\
\text { - Disable: not possible }\end{array}$ & $\begin{array}{l}\text { Integration: } 2 \\
\text { Easiness: } 2 \\
\text { Comfort: } 2 \\
\text { Transit distance: } 3 \\
\text { Transit time: } 3 \\
\text { Convenient facilities: } 3\end{array}$ \\
\hline $\begin{array}{l}\text { BTS to } \\
\text { Bus/Taxi/Motorbike } \\
\text { Taxi }\end{array}$ & $\begin{array}{l}\text { - Time required: 5-10 minutes } \\
\text { (depending on exit) } \\
\text { - Vertical distance: } 10 \mathrm{~m} \text { stair } \\
\text { - Horizontal Distance: } 50-150 \mathrm{~m} \\
\text { (depending on exit) }\end{array}$ & $\begin{array}{l}\text { - Vertical transport: stair } \\
\text { - Pathway within BTS: good, in } \\
\text { between: bad, at platform: bad, } \\
\text { disorder } \\
\text { - Disable: not possible }\end{array}$ & $\begin{array}{l}\text { Integration: } 2 \\
\text { Easiness: } 2 \\
\text { Comfort: } 2 \\
\text { Transit distance: } 3 \\
\text { Transit time: } 3 \\
\text { Convenient facilities: } 3\end{array}$ \\
\hline
\end{tabular}

Transit Process: BTS in Saphan Thaksin station is equipped with an escalator. However, transit for disabled people is not possible. Transit from BTS to riverboat is facilitated by Sathon Pier. The distance from the pier to the closest BTS exit is about $50 \mathrm{~m}$ through a crowd of food street vendors, Songteaw stand, and Tuktuk stand. The pathway is therefore inconvenient. The bus stand is available with a distance of 100 meters from the station. But the transit will not be convenient, as the pathway is uneven and crowded. It seems that this hub was planned when the surrounding areas have already developed, and thus makes the overall transit process is not convenient. The survey results at this hub are seen in Table 10.

\section{Modified Quantitative Gap Analysis}

There are numerous assessment tools for both qualitative and quantitative evaluations. Some of them are, for example, Affinity Charting, Analytical Hierarchy Process, Balanced Score Card, Cause and Effect, Gap Analysis, SWOT Analysis, Quantitative Decision Making, Total Quality Management, and many others. Gap Analysis is basically employed since the study attempts to 
understand the fact, as assessed by users and authors, against the ideal situation as preset by the authors based on some previous studies and authors' opinion. This study employs Modified Quantitative Gap Analysis (MQGA) with the following grounds: (a) to avoid subjective assessment as the original gap analysis identifies only existing and ideal condition, then gap based on the ideal and the existing states (b) to understand the gaps between existing and ideal condition (c) to identify the possible strategies to close the gaps.

To employ the MQGA, the evaluation by the users and authors are quantified. There are some variables used to assess the seamlessness of the transit system in Bangkok, namely, integration, easiness, comfort, transit distance, transit time, and convenient facilities. During the survey, plain explanations to avoid the ambiguity of the respondents were given. The following plain terms are given to the respondents during the survey.

Integration: the unity of premises/stations of BTS, MRT, ARL, Bus Stops (weighting factor, $w=0.2$ )

Easiness: transit will bring no various suffers to the users $(\mathrm{w}=0.2)$ Comfort: premise provides protection from the weather, provide air conditioners, easy and even walkways $(\mathrm{w}=0.2)$

Transit distance: relatively close, it does not create enforced walk (easy breathing) $(\mathrm{w}=0.15)$

Transit time: relatively short time, it does not make the travelers late and in rush $(\mathrm{w}=0.15)$

Convenient facilities: the premises are equipped with facilities such as stores, ATM, and toilets $(\mathrm{w}=0.10)$

A quantified respond is given to the respondents with the 5 -scale response, such as 1(worse), 2(bad), 3(satisfy), 4(good), 5(excellent).

A weighting factor for each element is introduced since each element does not have a similar contribution to the seamlessness. For instance, convenient facilities are only additional facilities for the overall function of the transit process, therefore the weighting factor is the lowest. On the other hand, the easiness, the comfort, the integratedness (integration of the premises of a transit hub) of the hubs are the most important elements. Therefore their weighting factors are the largest. Transit distance and transit time are normally the same elements, and thus the weighting factor is the same. The total weighting factors for all elements must be 1.0 .

The following formula is used to quantitatively identify each element of the seamlessness of a particular transit hub:

$$
c_{i}=\sum_{i=1}^{n} \frac{1}{n}\left[\left(r_{i}-\vec{r}\right)^{2}\right]^{0.5}
$$

And the seamlessness of a particular transit hub is computed by using the following formula:

$$
S_{i}=\sum_{i=1}^{n}\left(c_{i} \cdot w_{i}\right)
$$

$\mathrm{C}_{\mathrm{i}} \quad$ Element of seamlessness

$\mathrm{w}_{\mathrm{i}} \quad$ Weighting factor of each element of seamlessness

$r_{i} \quad$ Responses from the individual user on a particular issue

$\mathrm{S}_{\mathrm{n}} \quad$ Seamlessness of a transit process at the particular transit hub

$\mathrm{N}$ Number of sample of the transit hub

$\mathrm{n}$ Number of respondent who responds to a specific question

i Elements of the seamlessness

j Individual selected station

With the interval scale of response is 1.0 , the quantified criterion of seamlessness is divided into four into different intervals with the interval skewed towards seamless, the following criterion based on the quantified scale of the responses is as follows:

- Perfectly seamless i.e. easy and smooth transit if $\mathrm{Sn}<0.10$

- Somewhat seamless if Sn: 0.10-0.20

- Hard transit if Sn:0.21-0.50

- Not a smooth transit: $\mathrm{Sn}>0.50$

Performance of individual element at the different station is computed according to the following formula:

$$
p_{i}=\frac{1}{n} \sum_{i=1}^{n} r_{i}
$$

The seamlessness of overall Bangkok Transit Hub, based on six selected transit hub is computed by the following formula (assuming that each selected hub contributes to the Bangkok Transit System equally. Note: figure 6 in the formula exhibits the number of selected transit hub):

$$
S_{0}=\frac{1}{6} \sum_{i=1}^{6} S_{i}
$$

Based on 300 responses or 50 responses from each transit hub, by using the above formulas, the performance of each station in terms of individual elements of seamlessness, the seamlessness of individual elements, and the seamlessness of Bangkok Transit System based on selected hubs are shown in Table 9. And the performance of the individual hub on each element of the seamlessness is presented in Table 10.

Table 11 Seamlessness of individual hub

\begin{tabular}{l|r}
\hline Hub & Seamlessness (Sn) \\
\hline Mochit-Chatuchak Park & 0.54 \\
\hline Phayathai & 0.34 \\
\hline Makkasan-Petchburi & 0.35 \\
\hline Sukhumvit-Asoke & 0.49 \\
\hline Saladaeng-Silom & 0.47 \\
\hline Saphan Taksin-Sathorn & 0.42 \\
\hline Bangkok Overall & 0.43 \\
\hline
\end{tabular}

Perfectly seamless: $\mathrm{Sn}<0.10$

Somewhat seamless, Sn: 0.10-0.20

Hard transit, Sn: 0.21-0.50

Not a smooth transit, $\mathrm{Sn}>0.50$ 
Table 11 shows that, with respect to seamlessness of the transit hub in Bangkok Metropolitan none of the selected hub exhibits a perfect seamless transit as the seamlessness value is all above 0.10 . Two least values of seamlessness are shown by Phayathai and Makkasan-Petchburi Transit Hub, which are their values are 0.34 and 0.35 respectively. In fact, in Phayathai, for example, the distance among intermodal transports are so close, no more than 50 meters. The longest distance is between BTS and ARL, meanwhile the distance of other modes are between 10-20 meters. In Mochit-Chatuchak's case, the seamlessness is higher as the distance among intermodal transports are mostly, which is more than 50 meters. The farthest is between MRT and BTS, which is about 200 meters, and the path between the two is uneasy to pass.

Table 12 exhibits the average perceptions of the intermodal transit hub users, with the scale of 1 (worse) to 5 (excellent). Since these are the perceived values, the results are not definite, instead approximate to understand the level of six variables of the transit process for each selected hubs. It may or may not exactly represent the reality of public transport system in Bangkok in general.

Table 12 Performance of individual Hub on each element of seamlessness (based on 300 respondents)

\begin{tabular}{l|l|l|l|l|l|l}
\hline Hub & Integratedness & Easiness & Comfort & $\begin{array}{l}\text { Transit } \\
\text { Distance }\end{array}$ & $\begin{array}{l}\text { Transit } \\
\text { Time }\end{array}$ & $\begin{array}{l}\text { Convenient } \\
\text { Facilities }\end{array}$ \\
\hline Mochit-Chatuchak Park & 2.34 & 2.28 & 2.20 & 2.14 & 2.14 & 3.06 \\
\hline Phayathai & 2.80 & 2.80 & 2.02 & 2.92 & 2.84 & 2.14 \\
\hline Makkasan-Petchburi & 2.00 & 2.24 & 2.10 & 2.08 & 2.10 & 2.22 \\
\hline Sukhumvit-Asoke & 2.24 & 2.50 & 2.26 & 2.46 & 2.44 & 3.16 \\
\hline Saladaeng-Silom & 2.16 & 2.14 & 2.02 & 2.04 & 2.10 & 3.06 \\
\hline Saphan Taksin-Sathorn & 2.04 & 1.98 & 2.00 & 2.22 & 2.16 & 2.74 \\
\hline
\end{tabular}

NOTE: 1: Worse; 2: Bad; 3: Satisfactory; 4: Good, 5: Excellent

\section{Conclusions}

Six primary public transit hubs have been selected for the study, among about 17 existing hubs. Based on the responses of the transit users, and scientific judgment of the seamlessness referencing to sustainable transportation system, the transit process in Bangkok public transportation system, which involved formal, semi-formal and informal public transport namely Mass Rapid Transit System (MRT), Bangkok Mass Transit System (BTS), Airport Rail Link (ARL), State Railway of Thailand East Track (SRTET), Bangkok Bus System, Taxi, Motorbike Taxi, River Transport System, Songteaw, and private cars, exhibits a level of challenging transit process. Not to mention the transit process carried out by disabled and disadvantaged people.

With respect to the comfort of the individual premise of the station, as exhibited by Mass Rapid Transit System, Bangkok Mass Transit System, and Airport Rail Link, the user's perceptions reflected satisfactory responses, with MRT as the most satisfactory responses followed by BTS and ARL. In the meantime, the other public transport modes received unsatisfactory responses to the comfort of their platforms and shelters. However, when the assessment was done for overall integrity as a transit hub, the satisfaction of the users goes down significantly. This is understood as the system was planned and implemented individually without an appropriate integration. As a result, the transit process is not considered smooth, comfort and seamless by the users. The users were particularly assessed from the performance of pathways between the transport modes. To accomplish a more seamless transit process, the improvement must be made particularly on the pathways/walkways between the transport modes. Presently, the pathways perform differently with significant disparities, from worse to excellent.

The present of convenient stores, malls, ATM. Banks, or other service hubs and other facilities, have made the perception better. It is reflected in the user's perception of Mochit-Chatuchak, Saladaeng-Silom and Sukhumvit-Asoke Transit hubs, where convenient stores, malls, and other facilities are abundant. If these prospective facilities were impeccably treated to boost their potential to support the seamless transit, the perceptions would considerably improve. These are supposed to be attended by the authorities in Bangkok Metropolitan.

By these findings we understand that the transit processes in selected intermodal transit hubs in Bangkok do not reflect a seamless transit, and therefore the shift of private transport users to be public transport users will not take place. This happens since each elements of intermodal transport was not implemented at the same time, and by different authorities and implementers. A coordinated authorities led by Bangkok Metropolitan Administration should be established. A single plan or a coordinated transportation plan should also be in place, rather than silo-like plan.

\section{Acknowledgments:}

The supports of the Department of Civil Engineering, Faculty of Engineering, King Mongkut's Institute of Technology Ladkrabang, Bangkok Thailand are acknowledged. 


\section{References}

Airport Rail Link (2019). State Railway of Thailand East Track. Available online at http://www.srtet.co.th/index.php/en/?Itemid=146 (Retrieved on 30 April 2019).

Bangkok Bus Routes (2019). Routes of the Public Bus in Bangkok Metropolitan Region. Available online at https://www.transitbangkok.com/bangkok_bus_routes.php (retrieved on 2 May 2019).

BTS Skytrain (2019). Bangkok Mass Transit System Official Website. Available online at https://www.bts.co.th/eng/index.html (Retrieved on 30 April 2019).

Carmon, N., \& Fainstein, S. S. (Eds.). (2013). Policy, planning, and people: Promoting justice in urban development. University of Pennsylvania Press.

Chalermpong, S., A. Ratanawaraha, N. Maneenoy, and C. Chullabodhi (2018). Engineering Journal, 22(3): 1-10. DOI:10.4186/ej.2018.22.3.1

Günther, I and A. Launov (2012) Informal Employment In Developing Countries: Opportunity Or Last Resort? Journal of Development Economics. 97(1): 88-98

Haghshenas, H., \& Vaziri, M. (2012). Urban Sustainable Transportation Indicators For Global Comparison. Ecological Indicators. 15(1): 115-121.

Haque, M. M., Chin, H. C., \& Debnath, A. K. (2013). Sustainable, Safe, Smart-Three Key Elements Of Singapore's Evolving Transport Policies. Transport Policy. 27: 20-31.

Kamargianni, M., Li, W., Matyas, M., \& Schäfer, A. (2016). A Critical Review Of New Mobility Services For Urban Transport. Transportation Research Procedia. 14: 3294-3303.
Litman, T. (2015). Evaluating Public Transit Benefits And Costs. Victoria, BC, Canada: Victoria Transport Policy Institute.

Loo, B. P., \& du Verle, F. (2017). Transit-Oriented Development In Future Cities: Towards A Two-Level Sustainable Mobility Strategy. International Journal of Urban Sciences. 21(sup1): 54-67.

McCormick, K., Anderberg, S., Coenen, L., \& Neij, L. (2013). Advancing Sustainable Urban Transformation. Journal of Cleaner Production. 50: 1-11.

MRTA (2019). Mass Rapid Transit Authority of Thailand Official Website. Available online at https://www.mrta.co.th/en/ (Retrieved on 30 April 2019).

Permana, A.S., Gobi Krishna Sinniah, Rizon Pamardhi-Utomo, Rufia Andisetyana Putri (2018). Dual Formal-informal Transport Modes towards Quasi-seamless transit in Developing City. International Journal of Built Environment and Sustainability. 5(3): 224-240. DOI: https://doi.org/10.11113/ijbes.v5.n3.307.

Permana, A. S., Perera, R., Aziz, N. A., \& Ho, C. S. (2015). Creating The Synergy Of Land Use, Transport, Energy And Environment Elements Towards Climate Change Co-Benefits. International Journal of Built Environment and Sustainability, 2(1): 17-28 https://doi.org/10.11113/ijbes.v2.n1.53

Pugh, C. (2013). Sustainable Cities In Developing Countries. Routledge.

Schiller, P. L., \& Kenworthy, J. R. (2017). An Introduction To Sustainable Transportation: Policy, Planning And Implementation. Routledge.

Wikipedia (2019). Bangkok Metropolitan Region. Available online at https:/ / en.wikipedia.org/wiki/Bangkok_Metropolitan_Region (retrieved on 2 May 2019). 